\title{
The Impact of Innovation Strategy Toward Business Competitiveness of Manufacturing Industry in Surabaya, Indonesia
}

\author{
Slamet Riyadi ${ }^{1}$, Sumardi² \\ ${ }^{1}$ Universitas Dr Soetomo, Surabaya, Indonesia \\ ${ }^{2}$ Department of Management, Hasanuddin University, Indonesia
}

\begin{abstract}
This study aimed to examine and analyze the effect of administrative innovation on business competitiveness, technical innovations on business competitiveness, process innovation on business competitiveness, and product innovation on business competitiveness. This research conducted at manufacturing industry in Surabaya City, Indonesia. The number of samples was 100 business units, where the top manager or middle managers as the respondent. Methods of analysis use both descriptive statistical and Structural Equation Model (SEM). Data processed by IBM AMOS software. The results show that innovation strategy which consists of administrative innovation, technical innovation, process innovation, and product innovation can enhance organizational competitiveness in the manufacturing industry context. Administration innovation has a positive effect on business competitiveness. Technical innovation has a positive effect on business competitiveness. Process innovation has a positive effect on business competitiveness. Then, product innovation has a positive effect on business competitiveness. Process innovation has greater influence in improving business competitiveness compared to other innovation strategies.
\end{abstract}

Keywords: administrative innovation, technical innovation, process innovation, product innovation, business competitiveness, manufacturing industry

\section{Introduction}

Innovation is widely known both academicians and practitioners and it has been applied in the organization as one of the company's strategies to achieve competitive advantage in a global context. Cottam et al. (2001) says

*Corresponding author's email: slamet_riyadi08@yahoo.com ISSN: 2549-3221 (Print) 2549-323X (Online)

DOI: http://doi.org/10.26487/hebr.v111.1159 
that innovation is an alternative strategy for organizations to survive in a dynamic and volatile environment. According to Schumpeter (1934) innovation is concerned with the introduction of new products, processes, methods or systems within the organization. Esti and Suryani (2008) say that the concept of innovation is not just limited to the product development. Innovation can be ideas, methods, ways or objects perceived as something new in business. Innovation also refers to a novelty in organization activities. While Munizu (2014) considers innovation as parts of competitiveness. Information technology as one of the important elements in increasing business competitiveness within an organization.

Fontana (2009) describes innovation as the economic and social success due to new discoveries in transforming input to be output which creates major changes in offering products and services to consumers, communities and the environment. Then, the easiest way to detect innovation success is through checking for a number of new customers, sales growth, customer loyalty, and growth of profit margins (Wibisono, 2006).

Innovation has to do through a process that includes several steps i.e.: identifying problems, evaluating alternatives, making decisions, and implementing innovations in real actions (Cooper, 1998). The process by Roger (1995) mentioned as a diffusion of innovations. it means the dissemination of innovation from the source of discovery to the end user or adopter. Therefore in innovation, a company must develop a comprehensive innovation strategy. This strategy sets the company's goals for innovation by explaining what to innovate and how to achieve it. Integrating various activities that create creations, development, and commercialization of products and technologies enables companies to maximize the results from innovation efforts (Zahra and Das, 1993).

According to Jungwoo (2004) innovation always classified into two categories, namely administrative innovation and product innovation. Sungjoo et al. (2010) assert that product innovations in manufacturing companies related to all resources used in research and development activities (R\&D) such as research facilities and technical experts employed. Related to innovation, Damanpour (1991) classifies innovations into several types, such as administrative innovation, technical innovation, product and service innovation, process innovation, radical innovation, and incremental innovation. Continuously, and measurable innovation can help each organization to improve its business competitiveness. Porter (1985) says that when an organization begins to pay attention to the environment of global competition, innovation will be one of the key factors of success.

Based on several literature studies in management field, it can be identified that price or cost, quality, delivery, and flexibility as important elements of business competitiveness. Skinner in Krajewski et al. (2010) developed four priorities for competition: cost, quality, the speed of delivery, and flexibility to improve the performance and competitiveness of the organization. The study was done by Han et al. (2007) found that business competitiveness will increase through improvements in four dimensions i.e.: quality, cost, delivery, and flexibility.

\section{Conceptual Framework and Hypothesis}

The increasingly dynamic global environment has prompted many companies, especially manufacturing Industry use innovation as tools 
and strategy to win the competition. Continuously and consistently innovation will result in development, improvement and new discoveries. The innovation strategy can be done through administrative innovation, technical innovation, process innovation, and product innovation (Damanpour, 1991; Jungwoo, 2004). Innovation is one of the alternative strategies for an organization to win the competition in global markets (Cottam et al., 2001). Based on the description, the conceptual framework of this study can be presented in the following figure.

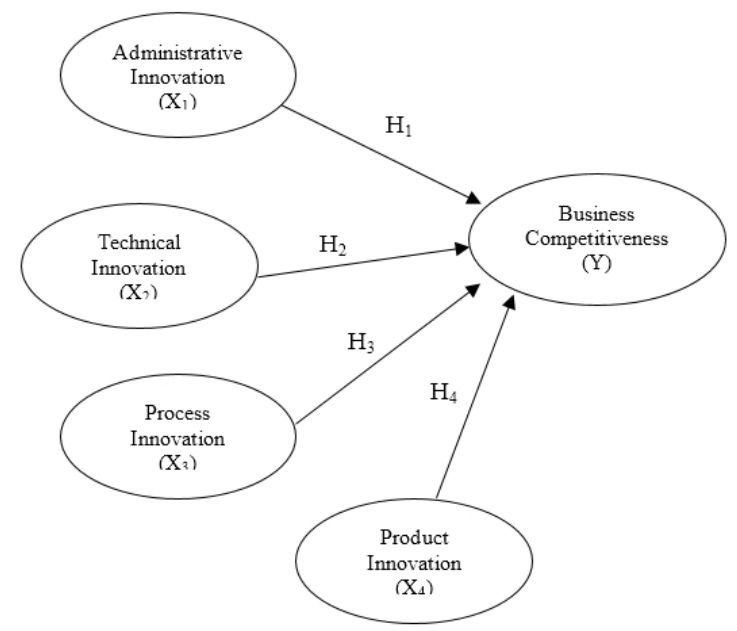

Figure 1. Conceptual Framework

Based on the results of theoretical study and the conceptual framework model above, it can be formulated research hypothesis as follows:

H1: Better administrative innovation will improve business competitiveness

H2: Better technical innovation will improve business competitiveness

H3: Better process innovation will improve business competitiveness

$\mathrm{H}_{4}$ : Better product innovation will improve business competitiveness

\section{Methodology}

This study used questionnaire instrument as the main tool in collecting data. Both observations and documentation also performed as additional data collection methods. Testing of instrument validity uses Pearson correlation, while instrument reliability was tested by using alpha Cronbach's method. The object of this research was manufacturing companies in Indonesia, especially in Surabaya City, East Java Province. The number of manufacturing industries (large and medium scale) recorded in 2015 as many as 816 units (BPS Surabaya, 2016). Then, determination of minimum sample size using Slovin formula at 10\% precision (Sekaran, 2008). Based on the formula, it can be obtained the minimum sample as 100 business units. The exogenous variables in this study were the innovation strategies adopted from Damanpour (1991) and Jungwoo (2004) which consist of administrative innovation, technical innovation, process innovation, and product innovation. While the endogenous variable was business competitiveness adopted from Han et al. (2007) includes 4 indicators namely: quality, cost, delivery, and flexibility. Then, variables and indicators measured by Likert Scale. It used to measure each indicator in the instrument by using a score of 1 to 5 (Hair et al., 1998). The method of analysis used in this research was both descriptive analysis and structural equation model (SEM). Furthermore, data was processing by using IBM AMOS software.

\section{Result and Discussion}

The result of hypothesis test to produce a fit model was using Structural Equation Modeling (SEM) analysis. Then, data was processed by using IBM AMOS 23 software. Complete results will describe a synergistic relationship among variable as presented in the following table. 
Hasanuddin Economics and Business Review

Vol. 1 No. 1 (83-89)

Table 1. The Result of Goodness of Fit Overall Model Test

\begin{tabular}{llll}
\hline $\begin{array}{l}\text { Criteria of } \\
\text { Goodness of Fit Index }\end{array}$ & Cut-off Value & Model Result & Description \\
\hline Chi square & smaller expected & 17,230 & Marginal \\
RMSEA & $\leq 0,08$ & 0,015 & Good \\
GFI & $\geq 0,90$ & 0,953 & Good \\
CMIN/DF & $\leq 2,00$ & 1,524 & Good \\
TLI & $\geq 0,95$ & 0,988 & Good \\
CFI & $\geq 0,95$ & 0,998 & Good \\
\hline
\end{tabular}

Source: Processing data, 2016

The results of the fit model test on the above table show that almost all criteria of goodness of fit index have been fulfilled. The value of GFI, RMSEA, and value of other criteria indicate the model being analyzed meets the criteria of a good model. Therefore, the model was good and it can be used to estimate the variables tested in this research. Furthermore, the results of hypothesis test were using structural equation modeling (SEM) can be presented in the following figure and table.

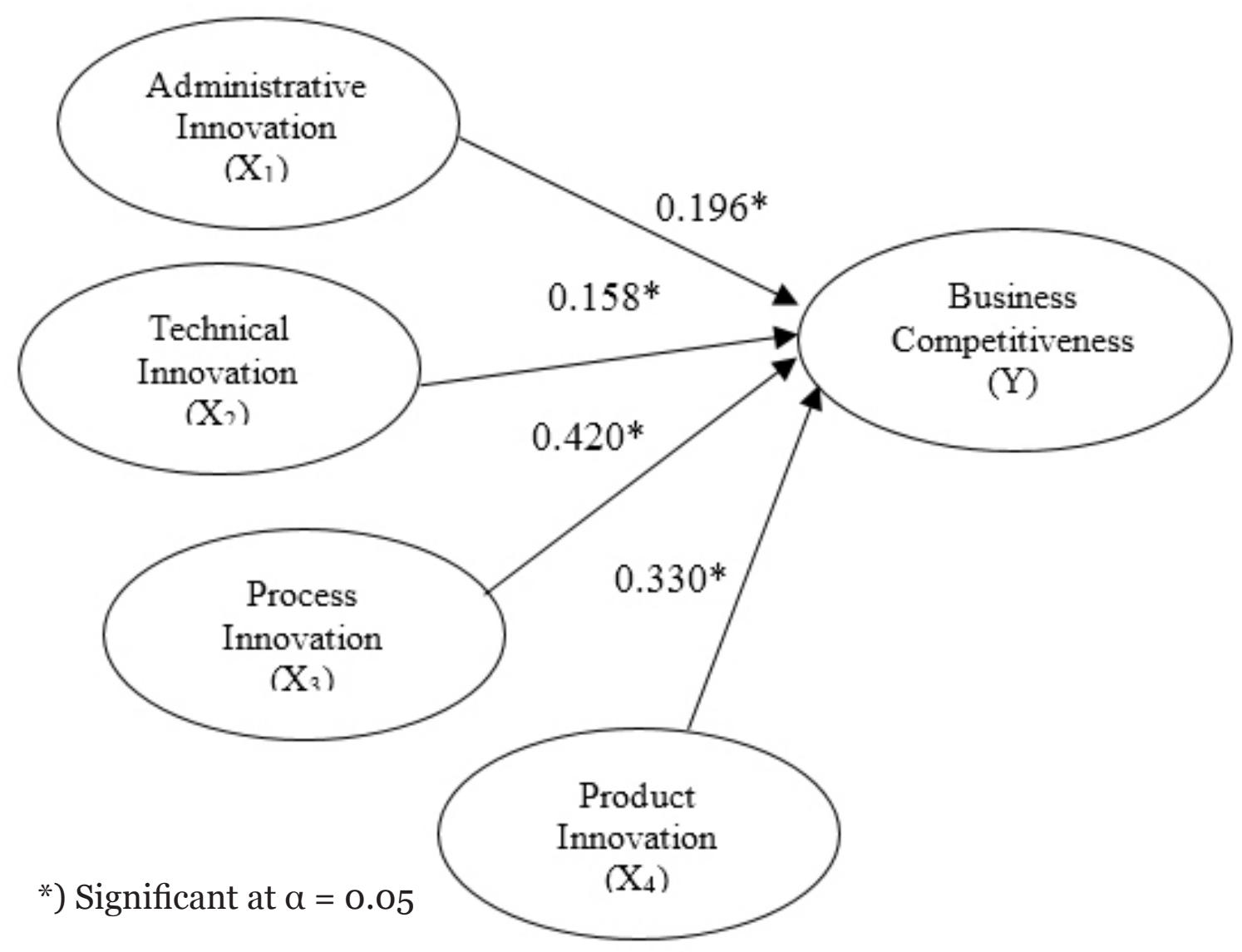

Figure 2. Empirical Model Result

(The Causal Relationship among Innovation Strategy and Business Competitiveness) 
Table 2. The Results of Hypothesis Test

\begin{tabular}{|c|c|c|c|c|}
\hline Variable & $\begin{array}{l}\text { Standardized } \\
\text { Regression }\end{array}$ & $\begin{array}{l}\text { Critical } \\
\text { Ratio }\end{array}$ & Prob. & Description \\
\hline $\begin{array}{l}\text { Administration Innovation --- } \rightarrow \\
\text { Business Competitiveness }\end{array}$ & 0.196 & 2.230 & $0.032^{*}$ & H1, accepted \\
\hline $\begin{array}{l}\text { Technical Innovation }--\rightarrow \text { Business } \\
\text { Competitiveness }\end{array}$ & 0.158 & 2. & $0.040^{*}$ & H2, accepted \\
\hline $\begin{array}{l}\text { Process Innovation }---\rightarrow \text { Business } \\
\text { Competitiveness }\end{array}$ & 0.420 & 4.866 & $0.000^{*}$ & $\mathrm{H}_{3}$, accepted \\
\hline $\begin{array}{l}\text { Product Innovation }---\rightarrow \text { Business } \\
\text { Competitiveness }\end{array}$ & 0.330 & $3 \cdot 570$ & $0.002^{*}$ & $\mathrm{H}_{4}$, accepted \\
\hline
\end{tabular}

Source: Processing data, 2016

*) significant at $\alpha=0,05 ; \mathrm{t}$-table $=1,980$

The results of hypothesis testing in the above table shows that variable of administrative innovation has a significant effect on business competitiveness. Where the value of the critical ratio was greater than standard value $(2.230>1.980)$ and probability value is smaller than alpha standard = $0.05(0.032<0.05)$. It indicates that the first hypothesis proposed in this study supported by empirical facts. Then, variable of technical innovation has a significant effect on business competitiveness. Where the value of the critical ratio was greater than standard value $(2.114>1.980)$ and probability value is smaller than alpha standard $=$ $0.05(0.040<0.05)$. It indicates that the second hypothesis proposed in this study supported by empirical facts.

Variable of process innovation has a significant effect on business competitiveness. Where the value of the critical ratio was greater than standard value $(4.866>1.980)$ and probability value is smaller than alpha standard $=$ $0.05(0.000<0.05)$. It indicates that the third hypothesis proposed in this study supported by empirical facts. In addition, variable of product innovation has a significant effect on business competitiveness. Where the value of the critical ratio was greater than standard value $(3.570>1.980)$ and probability value is smaller than alpha standard $=$ $0.05(0.002<0.05)$. It indicates that the fourth hypothesis proposed in this study supported by empirical facts. Based on the results of hypothesis testing above, it can be concluded that better innovation in administration, technical, process, and product can support increasingly business competitiveness within an organization.

Administrative innovation has a significant effect on business competitiveness with path coefficient as 0.196. It indicates that the better administration process will be increased business competitiveness. The results of this study supported Jungwoo (2004) and Fontana (2009) that assert better competitiveness determined by an increasingly effective job administration process in the organization. Administrative innovations based on the use of information technology such as databases, payroll systems, billing systemsweresomeexamplesofinnovation in the field of administration. Then, technical innovation has a significant effect on business competitiveness with path coefficient as 0.158 . Using of better technology to create products and service can support business competitiveness within an organization. The results of this study were in line with Damanpour (1991) and Jungwoo 
(2004) that business competitiveness determined by technological advances in the production of goods and services. Technical innovations can be observed in the use of CAD/CAM system in work centers or production division within an organization (Munizu, 2014).

Process innovation has a significant effect on business competitiveness with path coefficient as 0.420. Using the better process in production system can increase competitiveness. The results of this study were in line with Damanpour (1991) and Sabir et al. (2013) assert that business competitiveness was determined by an increasingly efficient production process in the organization. Then, product innovation has a significant effect on the business competitiveness with path coefficient as 0.330 . Therefore, the more innovative of resulting product, business competitiveness will be increased (Sungjoo et al., 2010).

The results of this study are in line with Damanpour (1991) and Sungjoo et al. (2010) that business competitiveness is determined by innovation on the products produced. Research activities and product development conducted in a plannedmannercanproducevarioustypes of features or new product variants that suit the needs and desires of consumers. In addition, the implementation phase is a critical success factor of innovation within an organization (Mat and Razak, 2013). Furthermore, the findings of this study consistent with Zarei and Baghban (2014) and Munizu (2014) who found the implementation of innovation as the key to success of UMKM in increasing their competitiveness.

\section{Conclusions and Suggestions}

This study has proved that innovation strategies that consist of administrative innovation, technical innovation, process innovation, and product innovation can enhance business competitiveness in the context of globalization. Administration innovation affected business competitiveness. Technical innovation affected business competitiveness. Then, Process innovation and product innovation also affected business competitiveness. Therefore, every organization can choose appropriate innovation strategy to compete in the globalenvironment.Innovationstrategies should be consistently was implemented by managers in the organization based on planning that has been formulated. In addition, managers must be able to combine the implementation of innovation strategies relied on organizational characteristics to obtain best results in driving of improvement of their business competitiveness, primarily on manufacturing industry in Indonesia.

Furthermore, the development of innovation includes administration innovation, technical innovation, process innovation, and product innovation based on information and technological advances and new methods in production process become a major consideration for improving the business competitiveness. Consequently, both knowledge and skill of managers are very important in understanding and implementing the types of innovation strategy as a tool in winning the competition in the global market. Implementation of innovation is a strategic decision is made by managers and using these strategies to accelerate the achievement of corporate goals.

\section{References}

BPS. (2016). Surabaya Municipality in Figures 2016. BPS Kota Surabaya Cooper, Juett R. (1998). A multidimensional approach to the adoption of innovation, Management Decision, 36(8): 493502 
Cottam A, Ensor J, Band C. (2001). A benchmark study of strategic commitment to innovation, Eur. $J$. Innov. Manage. 4(2): 88-94.

Damanpour, F. (1991). Organizational Innovation: A Meta-Analysis of Effects of Determinants and Moderators. Academy of Management Journal, 34(3): 555590.

Esti, R.dan Suryani, D. (2008). Potret Industri Kreatif Indonesia, Economic Review, Nomor 212, Jakarta.

Fontana, Avanti. (2009). Innovate We Can!. Jakarta: Grasindo

Han, S. Bruce, Chen, Shaw. K. Maling Ebrahimpour. (2007). The Impact of ISO 9000 on TQM and Business Performance. Journal of Business and Economic Studies 13 (2): 111120

Jungwoo, Lee. (2004). Discriminant Analysis of Technology Adoption Behavior: a case of internet technologies in small business, Journal of Computer Information System, 12: 57-66.

Krajewski, Lee J., Larry P. Ritzman, and K. Malhotra. (2010). Operation Management: Processes and Supply Chains, Ninth Edition, USA: Pearson Prentice Hall Inc.

Mat, Adam and Razak, Razli Che. (2013). Technological innovation implementation: A proposed model on organizational learning capability with moderating effect of knowledge complexity, African Journal of Business Management, 7(12): 926-935.

Munizu, Musran. (2014). Improving the competitive advantage through information technology: A case at food and beverage industries in Indonesia, Journal of Economics, Business, and Accountancy Ventura 17(3): 325 - 332
Porter, M.E. (1985). Competitive Advantage-Creating and Sustaining Superior Performance, USA: The Free Press

Rogers, E. M. (1995). Diffusion of Innovations, 4 th ed, USA: The Free Press.

Sabir, Hazoor Muhammad dan Kalyar, Masood Nawaz. (2013). Firm's Innovativeness and Employee Job Satisfaction: The Role of Organizational Learning Culture. Interdisciplinary Journal of Contemporary Research in Business, 4 (9): 670-686.

Schumpeter, J. (1934). The Theory of Economic Development, The MIT Press, Cambridge, MA

Sekaran, Uma. (2008). Research Methods or Business: A Skill Buiding Approach, 5nd ed. New York: John Willey \& Sons, Inc

Sungjoo, Lee, Park Gwangman, Yoon Byungun, Park Jinwoo. (2010). Open innovation in SMEs. An intermediated network Research Policy (30)1: 290-300.

Sutarno. (2012).Serba-serbi Manajemen Bisnis (Business Management Solutions), Edisi 1, Yogyakarta: Graha Ilmu

Wibisono, Darmawan. (2006). Manajemen Kinerja (performance management), Jakarta: Erlangga

Zahra, S. A. and Das, S. R. (1993). Innovation Strategy and Financial Performance in Manufacturing Companies: An Empirical Study, Production and Operation Management, 2(1): 15-37

Zarei, Vahid and Masoud baghban. (2014). Innovation Implementation to Support Iranian SMEs: Case Study in Oil \& Gas Beneficiary Company of Maroon, International Journal of Research in Social Sciences, 4(3):111-120. 